\title{
FREEDOM OF EXPRESSION OF THE MEDIA AND VIOLATION OF PERSONAL RIGHTS (CONSTITUTIONAL FRAMEWORK AND PRACTICE OF THE CONSTITUTIONAL COURT OF THE REPUBLIC OF CROATIA)
}

\author{
Marijana Majnarić, LLM \\ Constitutional Court of the Republic of Croatia \\ Trg Svetog Marka 4, Zagreb \\ marijana_majnaric@usud.hr
}

\begin{abstract}
In democratic societies, a lot of time and effort has been invested in creating the conditions for the freedom of the public media, setting impressive standards that must be respected but further developed. In their activities, the media is obliged to respect the personality of the people, that is, the freedom of man, therefore democratic societies must find ways to strike a balance between two fundamental rights, equal in value to the Constitution and the European Convention: the right to privacy and the right to freedom of expression. The problem arises when the media do not function in the service of the public interest but in the service of the immediate interest of the public (curiosity, sensationalism and desire for the highest circulation and profit), which inevitably entails acting outside the permissible limits. The state, through the judiciary, seeks to remedy violations resulting from freedom of expression, however, the Croatian judiciary still does not adequately respond to all the challenges posed by the daily development of the media, as well as those developed through the positions and principles of the Constitutional Court and the European Court of Human Rights. Perhaps one of the problems is that cases related to freedom of the media and infridgements of the rights of the person very rarely end up before the Supreme Court, which has one of the constitutionally guaranteed roles and that is harmonization of case law, so this type of cases are often resolved (closed) before lower instance courts. The Constitutional Court, like the European Court of Human Rights, has issued a significant number of decisions that have developed principles regarding freedom of expression, in particular freedom of expression of the media. The recent cases decided by the Constitutional Court are in support of the above, and in recent decisions it has decided principled positions that are applicable in all cases assessing a possible violation of freedom of expression, setting boundaries in the protection of freedom of expression and the protection of the rights of the person. In light of the above, the paper (analysis method and comparative method) will look at the constitutional framework of the right to freedom of thought and expression, to analyze the characteristics of
\end{abstract}


the right to freedom of expression, and to give an overview of the principled positions as well as the reasons why some constitutional complaints are upheld and some rejected, including a critical review of three decisions taken.

Keywords: freedom of expression, media, personality

\section{INTRODUCTION}

Freedom of expression, and therefore freedom of media, is regulated in all constitutions, declarations and laws. The most famous and shortest text regulating freedom of speech is the First Amendment of the United States Constitution ${ }^{1}$, which states that the Congress shall make no law abridging the freedom of speech, or the press. Freedom of speech is a fundamental human right, and this extends to freedom of the media, given that modern communication takes place through the media. Even though professional journalism should be based on truthfulness, fairness, accuracy, balance and impartiality, we witness that the media do not practice sufficient responsibility for the information they publish, leading to the rise of a sort of media "violence" whose victims are most often (exposed) individuals. Freedom of thought and expression are protected by Article 38 of the Constitution of the Republic of Croatia. ${ }^{2}$

Freedom of expression of thought entails freedom of press and other media, freedom of speech, freedom of public opinion, and freedom of establishment of all institutions of public communication. This freedom, however, is not absolute, given that Article 35 of the Constitution guarantees each citizen legal protection of their personal and family life, dignity, reputation and honor. In their practices, the media are obligated to respect human personality, in other words, individual freedom, so democratic societies must find ways to reconcile the highest standards of freedom of media workers and the highest standards in protection of freedom (personality) of citizens, which is sometimes jeopardized by these same media. These standards are adopted and, through its principled positions, upheld by the Constitutional Court in its more recent decisions. This topic has lately gained a lot of attention among the general public, as well as the legal and journalist professions. The paper consists of six chapters. Following an introductory overview, the second chapter discusses the characteristics of the right to freedom of thought and personality rights. The third chapter provides relevant legal foundations and restrictions to the right to freedom of expression. The fourth part deals with liability for damage. The fifth chapter analyzes Constitutional Court decisions, outlines

[http://www.prafak.ni.ac.rs/files/nast_mat/Ustav_SAD_sprski.pdf], Accessed 30 March 2020

Official Gazette No. 56/90, 135/97, 113/00, 28/01, 76/10 and 5/14, hereinafter the Constitution 
principled positions, and discusses reasons for upholding or rejecting constitutional complaints. Finally, the sixth chapter presents concluding remarks.

\section{RIGHT TO FREEDOM OF EXPRESSION}

According to some authors, the right to freedom of expression stems from the right to freedom of speech and "was created as a safeguard to those who hold opinions that differ from the state's or from the majority of its citizens. ." 3 Alaburić V. thinks the individual right to freedom of expression (as a fundamental personal right) is expanded by the democratic right of citizens to access information (collective political right of the public, i.e. the citizens). The right to freedom of expression is among fundamental political freedoms and rights derived by constitution-makers from the highest values of the constitutional order, above all - freedom. This is a constitutionally and conventionally established and protected human right and fundamental freedom and is elaborated according to standards of organic law to allow its further exercise and protection.

Taking into account the European Convention on Human Rights and Fundamental Freedoms ${ }^{4}$ (hereinafter: Convention), which clearly states in Article 10 that "everyone has the right to freedom of expression," and considering the constitutional position of the European Convention in the constitutional framework of the Republic of Croatia, it follows that the right to freedom of expression pertains to all natural persons and legal entities, citizens and foreigners, and to legal entities under the jurisdiction of the Republic of Croatia.

According to Article 38 of the Constitution, freedom of expression entails freedom of expression of thought, freedom of speech and public opinion, freedom of press and other media, and freedom of establishment of all institutions of public communication. Its restriction (like any other human right restriction) is possible only for the reason prescribed by Article 16 of the Constitution and in circumstances prescribed in Article 17 of the Constitution. ${ }^{5}$ However, the right to free-

Smerdel B., Ustavno uredenje europske Hrvatske, Zagreb, 2013, pp. 320-325

4 European Convention on Human Rights [https://www.echr.coe.int/Documents/Convention_ENG. pdf], Accessed 10 March 2020

5 Article 16 of the Constitution states: "Freedoms and rights may only be restricted by law in order to protect the freedoms and rights of others, the legal order, and public morals and health. Any restriction of freedoms or rights shall be proportionate to the nature of the need for such restriction in each individual case." Article 17 of the Constitution states: "Individual constitutionally guaranteed freedoms and rights may be restricted during a state of war or any clear and present danger to the independence and unity of the Republic of Croatia or in the event of any natural disaster.... The extent of such restrictions must be appropriate to the nature of the threat, and may not result in the inequality of citizens with respect to race, colour, gender, language, religion, or national or social origin." 
dom of expression is specific in relation to other rights and freedoms in that it is also affected by the constitutional prohibition from Article 39, stating that any call for or incitement to war or use of violence, to national, racial or religious hatred, or any form of intolerance shall be prohibited and punishable by law.

The right to correction of published information is protected by Article 38, paragraph 5 of the Constitution ${ }^{6}$, which implies the media have a right to make mistakes, but also establishes the right to legal action against the journalist or institution whose information violated the right of the natural person or legal entity. In the part pertaining to individual and political rights, the Constitution guarantees respect for and legal protection of each person's private and family life, dignity, and reputation (Article 35).

\subsection{Personality rights}

There is no unequivocal and final definition of personality rights. These are the rights inherent to each natural person, obtained upon birth. In Article 22, Paragraph 1, the Constitution states that a person's personality is inviolable. Personality rights encompass the right to life, to physical and mental health, reputation, honor, dignity, name, privacy of personal and family life, freedom etc. (per Civil Obligations Act ${ }^{7}$, Article 19, paragraph 2). Legal entities are also entitled to personality rights, other than the rights pertaining to the biological character of a natural person. Through such a general definition of personality rights, the Constitution enables their legal protection by determining a range of rights falling under its scope. In so doing, the COA leaves the range of personality rights open-ended, not limited by exhaustive enumeration, making the COA favorable to the injured party. In practice, however, this position requires additional effort on the judges' part in evaluating specific circumstances of the case, especially if the alleged violation is not described in the COA provisions. As a result, courts determine personality rights protection on a case-by-case basis, extending protection to personality rights not explicitly described in the COA. Given the importance this discussion places on the right to dignity, reputation and honor, we provide its definitions below.

In case law, violation of dignity is cited as a subjective impression a person has, caused by an external stimulus or offensive behavior of those in his or her sur-

Article 38, paragraph 5 of the Constitution states: "The right of correction is guaranteed to anyone whose constitutionally and legally established rights have been violated by public communication."

Official Gazette No. 35/05, 41/08, 125/11,78/15 and 29/18; hereinafter: COA 
roundings. ${ }^{8}$ Reputation is regarded as recognition of honor or dignity manifested or expressed as respect for the person in his or her social environment. ${ }^{9}$ Honor and dignity on the one hand, and reputation on the other, can be threatened by the act most commonly referred to as insult or defamation. Insult is defined as any belittlement or disrespect of another person's honor, dignity or reputation. Defamation is defined as asserting or disseminating in front of a third party a false claim about another person which can damage his or her honor or reputation in their social environment. ${ }^{10}$ Insults and defamation disseminated in the media are considered more severe, as they can result in a greater violation of personality rights.

The media generally retain the right to write about all public affairs, but they are obliged to check the facts and publish only truthful information. Citizens' reputation, honor, dignity and privacy must be respected. "Journalists may not, without consequence, make up (possibly for sensationalist purposes) factual and unverified information about a person, manipulate public opinion, publish superficial news or news of dubious origin." ${ }^{11}$

\section{RELEVANT LEGAL SOURCES}

The constitutional right to freedom of expression, as a human right and fundamental freedom, is developed in organic laws in accordance with the Constitution. Specifically, we will describe only a few organic law provisions relevant to understanding the concept and scope of the right to freedom of expression, and the applicable law governing the practice of the Constitutional Court and the ECHR. Apart from the constitutional provisions mentioned above, the legal basis for exercising and protecting freedom of expression and personality rights (their constitutional framework) are provisions of the European Convention and the Charter of Fundamental Rights, laws elaborating the right to freedom of expression, views held in individual cases by the ECHR and the Court of Justice of the European Union in Luxembourg, and the Constitutional Court of the Republic of Croatia.

\footnotetext{
8 Compare Supreme Court Judgment No. Revr-60/14 of 28 April 2015

$9 \quad$ Bačić F.; Pavlović Š., Komentar Kaznenog zakona, Organizator, Zagreb, 2004, p. 713

10 Articles 147 and 149 of the Criminal Code, Official Gazette No. 125/11, 144/12, 56/15, 61/15, 101/17,118/18 and 126/19; hereinafter: Criminal Code

11 Supreme Court Judgment No. Rev-2257/13 of 11 March 2014
} 


\subsection{The Convention}

The right to disseminate and receive different ideas and information is guaranteed in several international human rights documents, including Article 19 of the UN Universal Declaration of Human Rights ${ }^{12}$ and Article 19 of the International Covenant on Civil and Political Rights ${ }^{13}$. However, for the purposes of this paper, it suffices to cover the scope of the European Convention, the more so because it is informed by the original spirit of political ideals and tradition, respect for freedoms and the rule of law as the common tradition of the European civilizational and cultural circle, which Croatia is part of. Also, the jurisdiction of the ECHR is recognized in matters of human rights protection in the Republic of Croatia, and through the judicature of the ECHR, the interpretation of the content of those rights has gained a new dimension. In light of this, Omejec J. rightfully pointed out: "By the nature of things, it is moot to talk about compliance to the Convention, i.e. applying European Court practices, if the signatory state limits it to decisions made by this court in relation to the state in question. Namely, European constitutional standards stem from the totality of this court's jurisprudence." ${ }^{14}$

Article 10, paragraph 1 of the Convention guarantees every person the right to freedom of expression. This right entails freedom of thought, freedom to receive and disseminate information and ideas without interference from public authorities and regardless of frontiers. International sources of media law highlight three key conditions for restricting the freedom of media: a restriction may be prescribed by law, may be prescribed only to achieve specific interests, and only if it is necessary in achieving those interests. ${ }^{15}$ Article 10, paragraph 2 of the European Convention exhaustively predicts possible restrictions to media freedoms: protection of other persons' rights and reputation, preserving court authority and impartiality, national security, public health, public security, public order, preventing disorder or crime, and preventing disclosure of intelligence obtained in secrecy. As seen in the above, Article 10 of the European Convention does not specifically mention freedom of press or journalist freedom, but ECHR's judicature implies that the conventional formulation of freedom of expression entails freedom of the press, i.e. freedom of the media.

12 The Universal Declaration of Human Rights was adopted and enacted at the General Assembly of the United Nations, Resolution No. 217/III, on 10 December 1948

13 The International Covenant on Civil and Political Rights was adopted at the General Assembly of the United Nations, on 16 December 1966 (Resolution No. 2200 A/XXI), and came into force on 23 March 1976

14 Omejec, J., Načela i sredstva za priznavanje interpretativnog autoriteta presuda protiv drugih država iskustvo Ustavnog suda Hrvatske, Konferencija u Skopju, Republika Makedonija, 1-2 October 2010, Ministarstvo pravde Republike Makedonije u suradnji s Venecijanskom komisijom, p. 8

15 Vodinelić V., Pravo masmedija, Fakultet za poslovno pravo, Beograd, 2003, pp. 57-60 
The Convention guarantees the inviolability of every person's private and family life, home and correspondence, by a provision protecting citizens from unnecessary interference of the state in their privacy, except in cases of predominant public interest. Here it is also maintained that the right to respect and protection of privacy, dignity, reputation and honor is not an absolute right of citizens, and may be restricted in order to protect the guaranteed freedom of thought and expression, i.e. freedom of the media. A fundamental issue arises in how to resolve in a fair and proportional way possible conflicts between the right to freedom of expression and the right to respect and protection of personal and family life. This conflict should be resolved in a way that prevents the exercise of one right or freedom from encroaching on and suppressing the other, applying instead a degree of restriction to each of the conflicted rights, to preserve the other right or freedom. The principle in determining the limits of freedom of expression as opposed to the right to privacy is that of "justified interest."

\subsection{Media Act}

The Media $\mathrm{Act}^{16}$ is a fundamental act of Croatian media law. It is in nature an organic law replacing an older Public Communications Act. ${ }^{17}$ The content of the Media Act was harmonized with the European acquis, particularly the part pertaining to human rights and fundamental freedoms, and with Recommendations and Declarations of the Council of Europe. Provisions of the Media Act are applied and interpreted in accordance with the European Convention. This is because the ECHR, through its judicature, reserves the right to interpret the content of human rights protected by the European Convention and those violated by public authorities, requiring that interpretation of the Media Act be compatible with the ECHR's judicature.

In this manner, the Media Act prescribes what freedom of the media entails, what is prohibited, who has the right to protection of privacy and to which degree, as well as the level of privacy protection. While protecting values such as dignity, reputation and honor, the Media Act does not specifically define them.

\subsection{Civil Obligations Act}

In all matters otherwise or not at all regulated by provisions of the Media Act (lex specialis), provisions of the Civil Obligations Act (lex generalis) apply, according to the principle of subsidiarity. This is the case in the part regulating establishment

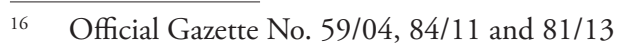

17 Public Communications Act, Official Gazette No. 83/96
} 
of liability for damage, but only where liability for damage is not otherwise regulated by the Media Act, which specifically pertains to exculpatory clauses from Article 21, paragraph 4 of said law. In this way, provisions of the COA complement provisions of the Media Act, and they are subject to cumulation (more on non-material damage below).

\section{DAMAGE LIABILITY}

In modern democratic states, personality rights of every person are subject to special protection. The right to compensation for non-material damage due to infringements of rights to reputation, honor and dignity stems from Articles 35, 37 and 38 of the Constitution.

The Media Act defines damage as the reduction of a person's property or prevention of its increase (material damage) and infliction of physical or mental pain or fear (non-material damage). ${ }^{18}$ The COA defines damage as reduction of someone's property (pure economic loss), prevention of its increase (loss of profit) and violation of personality rights (non-material damage). ${ }^{19}$ The main difference between ways of remedying the damage according to these two laws is that The Media Act, as a lex specialis, regulates remedying damage caused by publishing of information in the media, while the COA prescribes compensation for damage caused by any means.

In particular, Article 22 of the Media Act prescribes the following remedies for non-material damage: non-pecuniary - by publishing corrected information and publisher's apolog $y^{20}$ and pecuniary - by paying a compensation per general provisions of the Civil Obligations Act.

18 Article 21, paragraph 2 of the Media Act

19 Article 1046 of the COA

20 At the 4th Session of the Civil Law Department, No. Su-IV-270/17-10 of 18 December 2017, the Supreme Court adopted a new legal position on the issue of remedying non-material damage by issuing a final judgment in the media. It stated as follows: “... issuing a final judgment in the press is an acceptable form of remedying non-material damage to the injured party in a procedure regulated by the Media Act." The Supreme Court's current practice (upheld by the Constitutional Court's Decision No. U-III-1162/2012 from 9 May 2012) maintains the legal position that the provision of Article 22 of the Media Act does not include remedying non-material damage in the form of publishing the judgment awarding compensation to the injured party for non-material damage caused by publication of information in the media. Such practice, according to Ivica Crnić's view, is wrong, because Article 22 of the Media Act covers non-pecuniary remedies and states these, as a rule, consist of publishing a correction of information and publisher's apology. The expression "as a rule" does not preclude the injured party's right to have the remedy designated in the form of publishing the judgment. "With such an interpretation, the Supreme Court harms victims of the media, by depriving them of the right to have their remedy in the form of publishing the judgment which states that their personality rights 
The lawmaker's intention to resolve non-material damage disputes of this kind primarily out of court by providing redress to the injured party in the form of publishing a correction of contested information in the media, or an apology when correction is not possible, or in the form of reply to the published information. However, most disputes arising from publication of contested information are resolved in civil procedure and the injured party is awarded just pecuniary compensation.

Judging by relevant case law, publication of the final judgment, correction of information or apology ${ }^{21}$ do not entirely eliminate the damage. It should be taken into account that not all readers, listeners or viewers see or hear the apology or correction, nor do news on correction and apology spread as much as do those of the original (offensive) information. False, incorrect and offensive information has an impact and spreads even after a correction has been made. Corrections are often published (contrary to Article 41, paragraph 1 of the Media Act) inconspicuously, in the final pages, at the bottom of the page, and the correction text is often shortened and edited. For the above reasons, it is possible to cumulate requests for non-pecuniary compensation (Article 1099 of the COA and Article 22 of the Media Act) and requests for just pecuniary compensation (Article 1100 of the COA).

An injured party is entitled to file for compensation of non-material damage only if they have previously requested correction of contested information or publisher's apology where correction is not possible. Submission of this request is a procedural prerequisite for filing a claim ${ }^{22}$ for just pecuniary compensation. Just pecuniary compensation must take into account both the interests of the injured party and the interests of the community. It is therefore not acceptable to put a media outlet out of business by imposing too high a compensation, or to use it as a means of private punishment ${ }^{23}$. In individual claims judges have a great responsibility in striking a balance between the right to freely report on current events in the media and the right of each person to protection of reputation, honor, dig-

have been violated by the media." Crnić, I., Zakon o obveznim odnosima sizmjenama iz 2018. i dodatnom sudskom praksom, Organizator, Zagreb, 2018, pp. 1830 -1836

21 "The purpose of correction is to correct false or incomplete information. Publication of an apology pertains to offending statements, as only false statements can be corrected, and not offensive ones." Skoko, B., Objavljivanje neistina i manipuliranje činjenicama u hrvatskim medijima i mogućnost zaštite privatnosti, časti i ugleda, Politička misao, Zagreb, 2007, pp. 93-94

22 The claim may be filed not later than within three months from the day of learning about the publication of the information which caused the damage. This is treated as a preclusion period (Article 23 of the Media Act).

23 For example, in Austria, compensation in such cases in limited to 50,000 euros; in Italy the limit is 30,000 euros. Radolović, A., Odnos prava osobnosti i medijskog prava, Pravni fakultet Sveučilišta u Rijeci, 2007, p. 44 
nity, privacy and other personality rights from lies, defamation and insult. Once a court determines liability for damage, the judges decide the just compensation amount on the basis of their knowledge and experience, taking into account the circumstances of the present case. Therefore, in determining just pecuniary compensation, the court needs to consider the circulation of the media in question, as well as the width of the audience who had access to the information (e.g. whether the media outlet operates on a national, local, regional scale). Also, it needs to consider whether this information was circulated by other media, all while taking into account the injured party's personal and professional life and family status. ${ }^{24}$

When determining liability of media for damage, the ordinary court must take into account whether the published information is fact-based. "The facts are either there or not. They may be agreeable or disagreeable to the person they refer to, but they must be facts." ${ }^{25}$ This means courts must take into account whether research prior to publication was done by the media in good faith and in accordance with professional standards of fact-checking (per ECHR - the more serious the claim, the firmer its factual basis must be). ${ }^{26}$ The media are entitled to report on all events and are not liable for writing about a person in a negative context. However, if the claims are proved to be unfounded or constitute a severe breach of privacy, dignity, honor or reputation, the media should be aware of serious consequences such claims can have for the person targeted, and as such, the publisher is liable for them.

However, if the media report a person's statement (conversation, interview, statement at a public forum or public discussion) which is damaging to the person referred to, the person is responsible for their own statement. In conclusion, when deciding the media's liability for damage, ordinary courts must take into account all circumstances of the specific case, apply the principled positions of ECHR and the Constitutional Court, and come to a decision which will resolve in a fair and proportionate way the dispute between right to freedom of expression and right to respect and protection of private and family life.

24 For comparison, see Supreme Court Decision No. Rev-1114/09 of 15 October 2009. In this case, courts took into account the injured party's profession and family status

25 Supreme Court Decision No. Rev-1261/97 of 29 August 2001 and No. Rev-2257/13 of 14 March 2014; Constitutional Court Decision No. U-III-4056/03 of 5 July 2007

26 For comparison, see Constitutional Court Decision No. U-III-5408/08 of 4 April 2012, which references legal positions expressed in the case Europapress holding d. o. o. v. Croatia, No. 25333/06 of 22 October 2009, par. 66 


\section{PRINCIPLED POSITIONS AND CURRENT CASE-LAW OF THE CONSTITUTIONAL COURT}

Even though the Constitutional Court has taken its principled positions on the meaning, scope and limitations of freedom of speech in its earlier decisions, it still continues to develop its own case-law relevant to the need to protect freedom of expression, all while respecting and adopting recent case-law of the ECHR. In this manner, the Constitutional Court has adopted, in its recent decisions, a set of principled positions applicable in all cases related to violation of freedom of expression (freedom of the media) on the one hand, and protection of personality rights on the other. We outline them below.

Pluralism, tolerance, and freedom of thought, as foundations of "democratic society," require the right to freedom of expression to apply not only to "information" or "ideas" that are favorably received or regarded as inoffensive, but also to those that offend, shock or disturb. Exercising these freedoms entails responsibilities, which makes them subject to formalities, conditions, restrictions and penalties prescribed by law and necessary in democratic societies. Such restrictions must be unambiguously interpreted and reasonably justified (for comparison, see cases Guja v. Moldova and Bédat v. Switzerland). ${ }^{27}$

The right to freedom of expression is not an absolute right. Freedom of expression can be restricted if necessary in democratic society, and for this purpose a test of necessity was devised. The test of necessity in democratic society requires that the court handling the "claim" for restricting someone's freedom of expression determine whether such restriction is necessary and proportional to a legitimate goal in a democratic society, and provide sufficient and relevant reasons for doing so (for comparison, see Satakunnan Markkinapörssi Oy and Satamedia Oy v. Finland). ${ }^{28}$ Restriction of freedom of expression must be considered in the context of the entire case, including the content of statements and their context (compare Europapress holding d.o.o. v. Croatia). ${ }^{29}$

When assessing proportionality of interference, a distinction between facts and value judgments needs to be made. While the existence of facts can be demonstrated, the truth of value judgments can not, and as such should not be required. In order to distinguish whether a statement is a fact or a value judgment, circumstances of the case need to be taken into account, as well as the "general tone"

\footnotetext{
27 Guja v. Moldova, No. 14277/04, of 12 February 2008, par. 69 and Bédat v. Switzerland No. 56925/08 of 29 March 2016, par. 48

28 Satakunnan Markkinapörssi Oy and Satamedia Oy v. Finland, No. 931/13, of 25 June 2017, par. 164

29 Europapress holding d.o.o. v. Croatia, No. 25333/06 of 22 October 2009, par. 54
} 
of the contested statement, keeping in mind that statements on topics of public concern tend to be value judgments, and not facts (for comparison, see Morice $v$. France).$^{30}$

The media enjoy a broad scope of protection, which extends to journalists' research and inquiry prior to publication, as well as to protection of news sources (for comparison, see Goodwin v. United Kingdom and Sanoma Uitgevers B.V. v. Netherlands). ${ }^{31}$

Freedom of the media is conditional upon journalists' conduct in good faith and according to professional ethics (for comparison, see Stoll v. Switzerland and Pedersen and Baadsgaard v. Denmark). ${ }^{32}$

Freedom of media may not overstep certain limits, especially with regard to reputation and rights of others, but it should be maintained that its primary purpose is to convey information and ideas on all matters of public interest (in line with their obligations and responsibilities). Media have a duty to convey information and ideas, and the public has the right to receive them. If this were not the case, the media would not be able to exercise their role of "public watchdog" (for comparison, see Satakunnan Markkinapörssi Oy and Satamedia Oy and Magyar Helsinki Bizottság v. Hungary). ${ }^{33}$

When statements are given in political debate on a topic of public interest, only the most basic limitation of freedom of speech is acceptable. When it concerns politicians, limits of acceptable criticism are wider than with private individuals. Unlike private individuals, a politician has inevitably and knowingly exposed himself to close scrutiny of his every word and deed, and accordingly has to display a greater degree of tolerance (for comparison, see Sürek v. Turkey; Mladina d.d. Ljubljana v. Slovenia; Lingens v. Austria and Lopes Gomes da Silva v. Portugal). ${ }^{34}$

In determining whether a contested statement could affect protection of reputation and rights of others, this "conflict" needs to be resolved by evaluating relevant factors which include, on the one hand, right to freedom of expression, and on

\footnotetext{
30 Morice v. France, No. 29369/10 of 23 April 2015, par. 126

31 Goodwin v. United Kingdom, No. 17488/90 of 27 March 1996, par. 39. and Sanoma Uitgevers B.V. v. Netherlands, No. 38224/03 of 14 September 2010, par. 88-92

32 Stoll v. Switzerland, No. 69698/01 of 10 December 2007, par.103 and Pedersen and Baadsgaard v. Denmark, No. $49017 / 99$ of 17 December 2004, par. 78

33 Satakunnan Markkinapörssi Oy and Satamedia Oy, op. cit., par. 125 and 126; Magyar Helsinki Bizottság v. Hungary, No. 18030/11 of 8 November 2016, par.165

34 Sürek v. Turkey, No. 26682/95 of 8 July 1999, par. 61; Mladina d.d. Ljubljana v. Slovenia, No. 20981/10 of 17 April 2014, par. 40; Lingens v. Austria, No. 9815/82 of 8 July 1986, par. 42 and Lopes Gomes da Silva v. Portugal, No. 37698/97 of 28 September 2000, par.30
} 
the other hand, right to respect of others' personal life (for comparison, see Von Hannover v. Germany; Axel Springer AG v. Germany; Couderc and Hachette Filipacchi Associés v. France and Medžlis Islamske zajednice Brčko and others v. Bosnia and Herzegovina). ${ }^{35}$ Both rights warrant equal protection and courts have a duty to achieve a fair balance between them. In cases requiring balancing between the two values, the outcome should be the same for the person claiming another's public statement has damaged his or her dignity, honor or reputation as it would be in case of violation of freedom of expression of thought (for comparison, see Narodni list d.d. v. Croatia). ${ }^{36}$

To ensure consistency and avoid discretionary decisions regarding fair balance between conflicting rights in a particular case, ECHR listed several criteria for balancing the two in the case Axel Springer $A G$ : a) whether the publication contributes to a debate of general interest; $b$ ) how well known is the person concerned and what is the subject of the report; c) the prior conduct of the person concerned; d) the methods of obtaining the information and its veracity; e) the content, form and consequences of the publication; f) the severity of the sanction imposed and its chilling effect." 37

\subsection{Constitutional Court case No. U-III-458/2018}

The present case concerned articles published in "Večernji list" reporting on "controversial election" of a judge to the State Judiciary Council (for the third time), without constitutional grounds. The judge filed a claim against the publisher and was awarded, at the end of the proceedings, a 50,000.00 kuna compensation for non-pecuniary damage. The Constitutional Court upheld the complaint brought by the publisher, deciding that interference in freedom of expression, guaranteed by Article 39, paragraphs 1 and 2 of the Constitution, was not necessary in a democratic society.

Competent courts determined that the author of contested article made factual claims that the plaintiff should not have applied for office in the State Judiciary Council (hereinafter: SJC) and should not have been elected for it. They also found that the author of contested article did not act in good faith, given that he,

\footnotetext{
35 Von Hannover v. Germany (No. 2), No. 40660/08 and 60641/08 of 7 February 2012, par. 104 - 107; Axel Springer AG v. Germany, No. 39954/08 of 7 February 2012, par. 85 - 88; Couderc and Hachette Filipacchi Associés v. France, No. 40454/07 of 10 November 2015, par. 90 - 93 and Medžlis Islamske zajednice Brčko and others v. Bosnia and Herzegovina, No. 17224/11 of 27 June 2017, par.77

36 Narodni list d.d. v. Croatia, No. 2782/12, of 8 November 2018, par. 70

37 Constitutional Court Decision No. U-III-458/2018 of 23 May 2019
} 
having a degree in law, was familiar with the content of relevant legislation and its application.

In the present case, the Constitutional Court did not uphold the judgment of ordinary courts that the author of the article made factual claims. While it is indisputable that this is a topic of public interest, the Constitutional Court found that, in the present case, the author made a value judgment (personal opinion of the journalist on interpretation and application of constitutional and relevant law provisions), and not a statement of fact as per ordinary court decision. The journalist's opinion on interpretation of constitutional and other relevant provisions can not a priori be considered a statement made in "bad faith," nor can the complainant, as a lawyer by education (nor any other person), be denied the right to a different opinion on constitutional and other law provisions, even when it differs from the commonly held or "official" one. Ordinary courts established that the contested article could publicly hurt the dignity, honor and professional reputation of the claimant as a judge, impute to him behavior incompatible with duties of a judge, and as such provoke the average reader to take a negative view of the claimant as a judge, causing him damage, as occurred in the present case.

The Constitutional Court ruled such judgment as wrong, reasoning that the contested article was inoffensive and, contrary to the courts' opinion, found the content and context of the contested article did not contain criticism directed at the claimant, but rather criticism of the practice of the competent Committee and its alleged negligence in allowing the claimant to apply for office in the SJC for the third time. In conclusion, the Constitutional Court found that, in the present case, courts did not achieve a fair balance between constitutionally guaranteed conflicting rights of the claimant as judge and the complainant as a newspaper publishing company.

\subsection{Constitutional Court case No. U-III- 964/2017}

The present case concerned a claim lodged in civil procedure by a judge of Muncipal Court of Zadar against the publisher of "Zadarski list" for compensation of damage to honor and reputation caused by publication of an article about events in that court and the actions of its then president. The article claimed that the judge authored an anonymous letter detailing the situation in this court (comparing its president to Goebbels), which circulated among Zadar's public. Courts established that said article caused damage to claimant's reputation and honor and awarded her a 50,000.00 kuna compensation. 
The Constitutional Court decided that interfering in rights of the newspaper publisher was not necessary, considering the topic was one of public interest (administration of justice) which is subject to public criticism that may be wider in scope than is the case with ordinary citizens (as long as the criticism is in the public interest and based on facts).

The contested article reported on an anonymous letter regarding the Municipal Court of Zadar and its judges, only on the basis of a statement by the president of that court. Considering the claimant was a judge of this court, it could be asserted that this was a matter of predominant public interest and that publication of information on that event was part of the media's duty in democratic society. The complainant claimed the contested article did not represent his personal opinion or statement, and it was established that the contested article was published on the basis of a statement made by the court's president (which was confirmed by said president). Article 21, paragraph 4 of the Media Act stipulates that the publisher is not liable for damage if the damaging information is based on facts or on claims the author had reasonable grounds to believe to be true and took all required measures to check their veracity, there was legitimate public interest for its publication, and the author acted in good faith.

That courts did not give adequate explanation of the circumstances crucial for the decision on the compensation amount, nor did they explain how the fact that the complainant published a correction of the published article affected their decision. The Constitutional Court referenced ECHR's judgment in the case Buvač v. Croa$\mathrm{tid}^{38}$ that the purpose of correction is to allow the publisher to amend the inaccurate perception created among the public about the injured party, allowing him or her to repair the actual damage that could have occurred as a result of the incorrect publication in the media. It also remained unclear whether courts properly took into account that the amount of compensation awarded should not discourage the publisher from publishing similar information of public interest in the future.

The disputed judgments did not achieve fair balance between constitutionally guaranteed conflicting rights of the claimant as judge and the complainant's right to a guarantee of freedom of thought and expression of thought. The decision to uphold the complaint was made by majority decision with the dissenting opinion of one judge.

38 Buvač v. Croatia, No. $47685 / 13$ of 6 September 2018, par. 25 


\subsubsection{Comment on the above decision}

The author disagrees with the final judgment because the complainant did not fulfill basic conditions of acting in good faith, nor did he act in accordance with professional ethics he was obliged to. Taking into account that it was established in the proceedings that the complainant's journalist often writes what is not said and adds what she finds interesting, the president of the court said in a conversation with her that he does not know who wrote the letter, but that, judging by the vocabulary, he suspects it was the claimant. Also, the journalist said in her statement that she tried to contact the claimant in order to check the information (but it was her secretary who picked up), but the claimant said both she and her secretary were on leave during that time. In the present case, there was an omission in checking the veracity of the published information, whereas the value of the information does not contribute to a debate of significant public interest regarding the judicial system. Furthermore, the anonymous letter should have been analyzed in the context in which it was written, that is, internal relations between the judges of the court in question, which makes clear that the letter was not intended for the public, but rather for competent judicial authorities. In the present case, the claimant holds the office of judge, whose practice is essential to the rule of law. Given their role, the operation of courts should enjoy public confidence and protection from unfounded attacks. Courts, like other institutions, are not exempt from criticism and control, but this criticism should not overstep certain limits. Constructive criticism should be clearly distinguished from violations of reputation, honor and dignity on the basis of superficial information (and "exploiting" judges' personal relations), which was not taken into account by the complainant when they published the contested article. Considering all of the above, I think the constitutional complaint should have been rejected.

\subsection{Constitutional Court case No. U-III-2944/2018}

The complainant was ordered to pay the claimant a 20,000.00 kuna non-pecuniary damage compensation for emotional suffering caused to him by reports published in a column in "Novi list". The claimant filed a civil case for violation of personality rights, alleging that the complainant had made offensive and false claims against him. Ordinary courts decided that the manner in which the article was written and the expressions used indicate that the complainant had intention to offend, and that the work of the claimant could have been analyzed and criticized in a way that did not include offensive terms. They decided the complainant used unacceptable and offensive terms which should not be tolerated, and has thereby overstepped acceptable limits. 
The Constitutional Court decided that the second-instance court, in concluding that the complainant's aim was to offend the claimant, neglected the fact that limitations to freedom of thought and expression are considerably lesser in matters of public debate, and that the importance of the debate and the motives of the complainant in contributing to it (which were stated in said article) are not negligible. In the circumstances of the present case, the importance of public debate on said topics in a democratic society cannot be ignored. The Constitutional Court maintains that the complainant's freedom of expression in a public debate, even in the form of criticism directed at the claimant, when provoked by the claimant's stance relevant to the subject of the debate, is independent of whether the claimant was addressing the complainant or writing about him. In other words, the contested article by the complainant and his statements cannot be evaluated independently of the current public debate on that topic in our society (the debate on World War II and the advent of fascism in Croatia).

The Constitutional Court maintained that limits of acceptable criticism are wider when the criticism is directed at politicians, than is the case with private individuals.

By clearly stating his opinions on a topic subject to lively public debate, the claimant should have known it would provoke reactions from his opponents. Therefore he does not enjoy the same level of protection from criticism regarding his views as any other private individual, and the court should have taken this into account. Also, it was noted that the contested article was published in a section titled "Reactions" and it was clearly visible that this was the complainant's reaction (as a reader, not as a journalist) to a previously published article by the claimant. The Constitutional Court reminded that constitutional and conventional provisions on freedom of expression are not applicable only to information or ideas that are favorably received, or regarded as inoffensive or as a matter of indifference, but also to those that offend, shock or disturb.

The Constitutional Court concluded that fair balance was not achieved between constitutionally guaranteed conflicting rights of the claimant and the complainant, and established that the complainant's right to a guarantee of freedom of thought and expression, as vouchsafed in Article 38, paragraphs 1 and 2, was violated. 


\subsection{Constitutional Court case No. U-III-4336/2017}

The present case concerned the complainant's statements about the claimant (former director of HRT) ${ }^{39}$ made on HRT where he was presenting his candidate list for the local elections on 8 May 2013, after which he claimed that the claimant was a member of the counterintelligence agency of the former Socialist Federal Republic of Yugoslavia (hereinafter: KOS). The statement was later published on YouTube. The claimant alleged the complainant caused him damage in the form of personality rights violation, for which he was awarded just compensation of $30,000.00$ kuna in a civil procedure. The Constitutional complaint was rejected because it was established that interfering with the complainant's freedom of expression was proportional to a legitimate cause - protection of claimant's reputation and honor.

It was established that the statement was false and that it did not contribute to public debate, confirming the decision of the second-instance court. Prior to making the statement, the complainant was interrupted in making a statement that was to be aired on HRT as part of the election campaign, because HRT staff considered it inappropriate and offensive in content. After that, the complainant made negative comments about the event in front of the HRT building, protesting the interruption, claiming it was censorship, and calling HRT staff derogatory names.

The Constitutional Court concluded that alleged or actual prior tolerance of previously made claims about the claimant as a KOS agent does not deprive the claimant of the right to protection of his private life. Given the circumstances in which it was given, the contested statement intended to present the claimant as a member of the former state's counterintelligence agency, which is in itself dishonorable, and all with the aim of harming his reputation and honor. The Constitutional Court determined that the complainant did not act in good faith in making the contested statement. The complaint was rejected by majority decision, with two dissenting opinions.

\subsubsection{Comment on the above decision}

The author disagrees with the final decision, because the statement in question was a value judgment of the complainant and part of public debate, and his right to freedom of expression was violated. In the proceedings, ordinary courts insisted that the complainant prove the veracity of his claims, which they ultimately characterized as a statement of fact. This raises the question of how criteria for free-

39 Croatian Radiotelevision 
dom of expression will subsequently be evaluated and established in the context of political debates and presentations of political programs, given the fact that it is customary in such circumstances to exhibit offensive, shocking, and disturbing behavior, alongside (in these parts, at least) frequent mentions and "exhumations" of former regimes and imputing participation therein. In conclusion, specific circumstances of the present case should have been taken into account. Public figures directly involved in election processes may not invoke the right to protection of reputation, because election processes favor the public interest of freedom of expression and freedom of political speech (for comparison, see ECHR in the case Karako v. Hungary). ${ }^{40}$ In this context, it was determined that there is only an appearance of conflict of conventional rights to respect of private and family life and the right to freedom of expression (paragraph 17 of the Judgment). In the context of the present case (statement), a relevant interpretation to be considered is the case Ungváry and Irodalom Kft. v. Hungary, ${ }^{41}$ in which the ECHR established a violation of Article 10 of the Convention in sanctioning an individual for making a statement claiming that a judge of the Constitutional Court of Hungary previously cooperated with communist Hungary's secret services. Considering all of the above, I think the constitutional complaint should have been upheld.

\subsection{Constitutional Court case No. U-III-1084/2015}

The present criminal procedure concerned the complainant's statement in an interview published on an online portal, in which, when asked by a journalist "Stipe Mesić claimed that veterans gathered in the Defense Headquarters of Croatian Vukovar are the same as Serb rebels in 1991. What is your opinion?", he answered "Stipe is an idiot."

The present case was a criminal procedure against the complainant, filed by the former Croatian president, claiming a criminal offense against honor and reputation committed by insult in the form of a statement made on an online portal. The contested statement by the complainant was given in an interview, as an answer to a journalist's question, and as an opinion on a statement made by the private plaintiff, and the author titled the article "Mesić is an idiot..." Ordinary courts established that the complainant offended the private plaintiff by claiming he is an idiot, the publication of which was accessible to a large number of people. For the criminal offense of insult, the complainant was ordered to pay a compensation of 10,000.00 kuna. Courts established that the complainant had the intention of

\footnotetext{
40 Karako v. Hungary, No. 39311/05 of 28 April 2009, par. 27-28

41 Ungváry and Irodalom Kft. v. Hungary, No. 64520/10 of 3 December 2013
} 
humiliating and belittling the private plaintiff personally and before the general public.

The complainant claimed that the aim of the contested statement was to condemn the private plaintiff's controversial view. The Constitutional Court concluded that this was a value judgment and not a factual claim and that the complainant was asked to give an opinion on a topic of public interest, wherein both participants are public figures and politicians, and that the complainant's statement was taken out of context. It decided that courts failed to establish all the circumstances of the present case, and failed to provide grounds that it was a criminal offense. It also found that they did not establish the existence of predominant public interest to favor the protection of personality rights of the private plaintiff over the complainant's right to freedom of expression, and insomuch failed to achieve fair balance, whereupon the complaint was upheld. The decision was made by majority, with three dissenting opinions.

\subsubsection{Comment on the above decision}

The author disagrees with the final decision, because a statement made in such a way does not constitute a value judgment. It was directed at the private plaintiff and not the context of what he said and it was not given in good faith - it constitutes an attack on his dignity. The more so because the complainant, as a writer and an intellectual, was aware of the meaning of the words uttered, and the fact he was thereby directly belittling the private plaintiff. Ordinary courts provided detailed statements of reasons with their decisions, including the reasoning that, when someone calls another person an idiot, this cannot be well-intentioned and that it undoubtedly indicates the defendant's intention to humiliate and belittle the private plaintiff personally and before a large public. The topic of the interview were various current events to which the complainant responded by giving his views and opinions. However, when asked to give his opinion on the private plaintiff's statement, he responded with the contested insult. In so doing, he did not express an opinion about his statement, but about his person. For this reason, protection of the right to expression of thought may not be favored over protection of the private plaintiffs right to dignity, especially if the behavior is offensive and demeaning. Insult, humiliation, and hate speech are not protected under Article 10 of the European Convention (for comparison, see ECHR judgment in Rujak v. Croatia). ${ }^{42}$ For the above reasons, I think the constitutional complaint should have been rejected.

42 Rujak v. Croatia, No. 57942/10 of 2 October 2012, par. 28-30 


\section{CONCLUSION}

The media have an active role in political life and elsewhere, considering they promote discussion on matters of public interest. The scope of freedom of expression in the media is interpreted widely, given their assigned role of "public watchdog." In that regard, the European Parliament states in its Resolution 1165: "Personal privacy is often invaded, even in countries with specific legislation to protect it, as people's private lives have become a highly lucrative commodity for certain sectors of the media." ${ }^{43}$ In light of the above, protection within the judicial framework will remain an important factor in protecting infringed rights and interests and achieving their fair balance. It is therefore necessary to ensure that the rapidly increasing development of the media and their freedoms is accompanied by a high-quality judicial system. New criteria for submitting revisions to the Constitutional Court will undoubtedly have an impact in this context. ${ }^{44}$ As a consequence of these changes, and taking into account the now abundant case-law of the Constitutional Court and the ECHR, ordinary courts will be able to adequately respond to challenges in resolving cases formerly "reserved" for the Constitutional Court. Weighing decisions based on circumstances of each particular case does not oblige only ordinary courts but also the Constitutional Court itself, and in this context the author provided commentary on the three decisions described above. Cases related to freedom of expression on the one hand and protection of personality rights on the other are among the most complicated and "living" proceedings. Alongside their guaranteed standards of freedom of expression, the media have the responsibility to apply their own standards of professionalism in respecting the personal rights of everyone else. The judicial system as a whole, and the Constitutional Court in particular, are to keep building and developing their case-law with the aim of protecting freedom of expression and personality rights.

43 [http://www.europarl.europa.eu/doceo/document/TA-8-2018-0204_HR.html], Accessed 30 March 2020

44 Until the latest amendments to the Civl Procedure Act, the value of the subject of the dispute for submitting regular revisions was "set too high," while exceptional revisions required an important issue from article 382, Paragraph 2 of the CPA. However, recent amendments to the CPA, Official Gazette No. 70/19, effective from 1 September 2019, removed the criterion of value and introduced revision on request by the Supreme Court (which has to be in the public interest - this was previously reserved for exceptional revisions; Article 382). These changes apply to all cases in which the second-instance decision was made after 1 September 2019 [https://www.zakon.hr/z/134/Zakon-o-parni\%C4\%8Dnom-postupku], Accessed 30. March 2020 


\section{REFERENCES}

\section{BOOKS AND ARTICLES}

1. Bačić, F.; Pavlović Š., Komentar Kaznenog zakona, Organizator, Zagreb, 2004

2. Crnić, I., Zakon o obveznim odnosima s izmjenama iz 2018. i dodatnom sudskom praksom, Organizator, Zagreb, 2018

3. Omejec, J., Načela i sredstva za priznavanje interpretativnog autoriteta presuda protiv drugih država - iskustvo Ustavnog suda Hrvatske, Konferencija u Skopju, Republika Makedonija, 1-2 listopada 2010, Ministarstvo pravde Republike Makedonije u suradnji s Venecijanskom komisijom

4. Radolović, A., Odnos prava osobnosti i medijskog prava, Pravni fakultet Sveučilišta u Rijeci, 2007

5. Skoko, B., Objavljivanje neistina i manipuliranje činjenicama u hrvatskim medijima $i$ mogućnost zaštite privatnosti, časti i ugleda, Politička misao, Zagreb, 2007

6. Smerdel, B., Ustavno uređenje europske Hrvatske, Zagreb, 2013

7. Vodinelić, V., Pravo masmedija, Fakultet za poslovno pravo, Beograd, 2003

\section{EUROPEAN COURT OF HUMAN RIGHTS}

1. Guja v. Moldova, No.14277/04, judgment dated 12 February 2008

2. Bédat v. Switzerland, No. 56925/08, judgment dated 29 March 2016

3. Satakunnan Markkinapörssi Oy and Satamedia Oy v. Finland, No. 931/13, judgment dated 27 June 2017

4. Europapress holding d.o.o. v. Croatia, No. 25333/06, judgment dated 22 October 2009

5. Morice v. France, No. 29369/10, judgment dated 23 April 2015

6. Goodwin v. United Kingdom, No. 17488/90, judgment dated 27 March 1996

7. Sanoma Uitgevers B.V. v. Netherlands, No. 38224/03, judgment dated 14 September 2010

8. Stoll v. Switzerland, No. 69698/01, judgment dated 10 December 2007

9. Pedersen and Baadsgaard v. Denmark, No. 49017/99, judgment dated 17 December 2004

10. Satakunnan Markkinapörssi Oy and Satamedia Oy and Magyar Helsinki Bizottság v. Hungary, No. 18030/11, judgment dated 8 November 2016

11. Sürek v. Turkey, No. 26682/95, judgment dated 8 July 1999

12. Mladina d.d. Ljubljana v. Slovenia, No. 20981/10, judgment dated 17 April 2014,

13. Lingens v. Austria, No. 9815/82, judgment dated 8 July 1986

14. Lopes Gomes da Silva v. Portugal, No. 37698/97, judgment dated 28 September 2000

15. Von Hannover v. Germany (No. 2), No. 40660/08 and 60641/08, judgment dated 7 February 2012

16. Axel Springer AG v. Germany, No. 39954/08, judgment dated 7 February 2012

17. Couderc and Hachette Filipacchi Associés v. France, No. 40454/07, judgment dated 10. November 2015 
18. Medžlis Islamske zajednice Brčko and others v. Bosnia and Herzegovina, No. 17224/11, judgment dated 27 June 2017

19. Narodni list d.d. v. Croatia, No. 2782/12, judgment dated 8 November 2018

20. Buvač v. Croatia, No. 47685/13, judgment dated 6 September 2018

21. Karako v. Hungary, No. 39311/05, judgment dated 28 April 2009

22. Ungváry and Irodalom Kft. v. Hungary, No. 64520/10, judgment dated 3 December 2013

23. Rujak v. Croatia, No. 57942/10, judgment dated 2 October 2012

\section{EU LAW}

1. European Convention on Human Rights as amended by Protocols Nos. 11 and 14 and supplemented by Protocols Nos. 1, 4, 6, 7, 12, 13 and 16

2. The Universal Declaration of Human Rights was adopted and enacted at the General Assembly of the United Nations, Resolution No. 217/III on 10 December 1948

3. International Covenant on Civil and Political Rights was adopted at the General Assembly of the United Nations, Resolution No. 2200 A /XXI on 16 December 1966 (effective 23 March 1976)

\section{LIST OF STATE LAWS, ACTS AND COURT JUDGMENTS}

1. Constitution of the Republic of Croatia, Official Gazette No. 56/90, 135/97, 113/00, 28/01, 76/10 and 5/14

2. Civil Obligations Act, Official Gazette No. 35/05, 41/08, 125/11,78/15 and $29 / 18$

3. Media Act, Official Gazette No. 59/04, 84/11 and 81/13

4. Criminal Code, Official Gazette No. 125/11, 144/12, 56/15., 61/15, 101/17, $118 / 18$ and $126 / 19$

5. Public Communications Act, Official Gazette No. 83/96

6. Civil Procedure Act, Official Gazette No. 53/91, 91/92, 112/99, 88/01, 117/03, 88/05, 2/07, 84/08, 96/08, 123/08, 57/11, 148/11, 25/13, 28/13, $89 / 14$ and $70 / 19$

7. Constitutional Court Decision No. U-III-5408/08 of 4 April 2012

8. Constitutional Court Decision No. U-III-4056/03 of 5 July 2007

9. Constitutional Court Decision No. U-III-964/2017 of 26 June 2019

10. Constitutional Court Decision No. U-III-2944/2018 of 26 June 2019

11. Constitutional Court Decision No. U-III-4336/2017 of 26 June 2019

12. Constitutional Court Decision No. U-III-458/2018 of 23 May 2019

13. Constitutional Court Decision No. U-III-1084/2015 of 10 December 2019

14. Supreme Court Decision No. Revr-60/14 of 28 April 2015

15. Supreme Court Order No. Rev-2257/13 of 11 March 2014 
16. Legal position of the Supreme Court No. Su-IV-270/17-10 of 18 December 2017, Hrvatska pravna revija, May/June 2018

17. Supreme Court Decision No. Rev-1114/09 of 15 October 2009

18. Supreme Court Decision No. Rev-1261/97 of 29 August 2001

19. Supreme Court Decision No. Rev-2257/13 of 14 March 2014

\section{WEBPAGES}

1. [http://www.prafak.ni.ac.rs/files/nast_mat/Ustav_SAD_sprski.pdf], Accessed 30 March 2020

2. [https://www.echr.coe.int/Documents/Convention_ENG.pdf] Accessed 10 March 2020

3. [http://www.europarl.europa.eu/doceo/document/TA-8-2018-0204_HR.html], Accessed 30 March 2020

4. [https://www.zakon.hr/z/134/Zakon-o-parni\%C4\%8Dnom-postupku], Accessed 30 March 2020 